\title{
A Szibenliszt Bélának készült kanászbalta
}

\author{
BERZY PÉTER
}

H-7400 Kaposvár, Kontrássy utca 5.

BERzY, P.: Swine Heard Axe titled to Bela Szibenliszt. Abstract: Description of a swine heard axe dedicated to Bela Szibenliszt and its connection to the named person.

Keywords: carving, folk art, Várda, Somogy county.

\section{Bevezetés}

Jelen tanulmányban szerző célja a magángyűjteményében őrzött kanászbalta leírása és a nyélen szereplő név tulajdonosával, Szibenliszt Bélával való kapcsolatának bemutatása. Néprajzi tárgyi gyüjteményének ez az értékes darabja az 1970-es években került a szerzőhöz, a Somogy megyei Várda községből. Kinézetre hagyományos régi somogyi kanászbalta, kissé görbe, jól kézre álló nyéllel, acél balta fokkal. A nyél felső vége spanyolozással, egész hosszában karcolozással díszített. Nem csak dísztárgy volt, hanem használatban lehetett, mert a nyél csiszoltsága, a nyél alsó végének kopása, deformációja, valamint a balta élének apró csorbulásai is erre utalnak.

A kanászbalta jellemzően a külterjes tartásban (rideg módra) legeltetett disznókat őrző kanász eszköze volt. ${ }^{1}$ A szabadban makkoltató pásztorok az állatok terelése mellett favágásra, önvédelemre és még pásztortáncukban is felhasználták. A balta lapjával való eldobása külön tudomány volt, oldalba hajítva az állatot visszaterelte a helyes útra anélkül, hogy kárt tett volna benne. ${ }^{2} \mathrm{~A}$ felbőszült kanok közé dobva, vagy a fókába (más néven falkába) betörő idegen vaddisznókat is távol lehetett tartani vele. A verekedéseikről elhíresült kanászok a kocsma mestergerendájába állítva tartották, amíg ittak; a baltát csak annak tulajdonosa vehette ki onnan. ${ }^{3} \mathrm{~A}$ betyárok és a rablók támadásai ellen is ezzel védekezett a kanász. Jó célt szolgált tüzifa vágáskor, vagy akár egy-egy disznó leütésekor is. Mint nélkülözhetetlen eszköz, a kanászmesterség szimbólumává vált. ${ }^{4}$

A kanászbalta elnevezése vidékenként változott: pásztorbalta, kanászbalta vagy kanászszerszám, kondásbalta, hordozófejsze, valaska, balloska, balaska. Veszprém megye 1791-ben már rendeletileg betiltotta tartását és elrendelte az elkobzását. 1822-ben ismét megerősítették a tiltó rendelkezést, melynek következményeként a pásztorok bár használták ugyan a balaskát, elrejtették azt.
A somogyi kanászok rátartiságáról maga Herman Ottó is megemlékezett. A finom megmunkáltság, tökéletes forma mellett a cifra díszítés arról tanúskodott, hogy a mesterség státuszszimbólumaként és presztizstárgyként tekintettek a baltára. Azok a balták, amelyek oldalába ezüstforint nagyságú tükrök voltak „beeresztve”, minden bizonnyal veszítettek funkcionális értékükből és inkább ünnepi darabok lehettek.

Népi faragóink is megörökítették a kanászokat, pásztorokat karcolozott, faragott tárgyaikon, például készítettek Somogyban olyan szaru sótartót, melyen az elfogott betyárt kisérő pandúr kezében van a bünjel, egy kanászbalta. Bár a mezőgazdasági termelés belterjessé válásával megszűnt a rideg pásztorkodás és kikopott a balta eredeti használata, dísztárgyként és a másolatai szuvenírként kedvelt ajándéktárgyak maradtak.

A szintén szerző gyűjteményének részét képező, Ékes János igali juhász által készített, 1896-ra datált sótartón a betyároknál puska és balta látható, miközben itcéből borozgatnak az erdőben. A sótartó hátlapján (1. ábra) látható borozó jelenetben a baltájukat egy lombos fába vágva ábrázolta az alkotó.

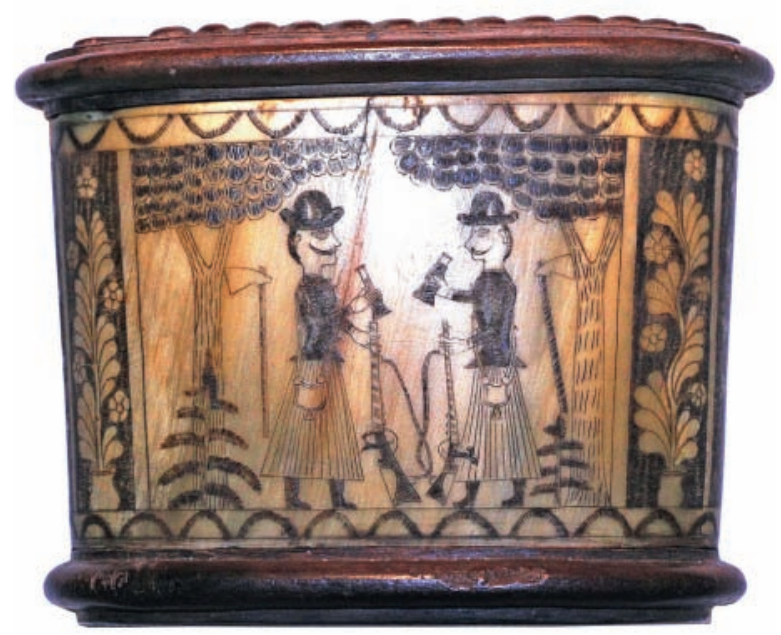

1. ábra. Szaru sótartó hátoldala

1 Tálasi I. 1939, 33-34

2 Takáts Gy. 1986, 14.

3 Eötvös K. 1901, 81-82.

4 Malonyay D. 1911, 95 


\section{A balta leírása}

A balta teljes hossza $102,5 \mathrm{~cm}$ (2. ábra). A nyél alsó átmérője $2,7 \mathrm{~cm}$, felső átmérője $3 \mathrm{~cm}$. A fej méretei: élhossza $9 \mathrm{~cm}$, legnagyobb külső ívhossza $16 \mathrm{~cm}$, belső hossza $13,5 \mathrm{~cm}$, fok hossza $1,7 \mathrm{~cm}$, a nyélnél a legszélesebb mérete $3,7 \mathrm{~cm}$, nyél lyuk átmérője $3 \mathrm{~cm}$.

A nyél anyaga feltehetöleg gyertyánfa, két sötétebb csomóval, színe világos barna, drapp, természetes nyers fa színű, a használattól kifényesedve. A nyél súlya $44 \mathrm{dkg}$. A balta a nyélre a görbülethez képest kifelé álló éllel van szorosan ráhúzva, a nyél felső végétől mintegy $1-1,5 \mathrm{~cm}$-re kezdődően. A fa nyél és a fém balta között vékony rongy tekerés van a felszorítás miatt, valószínű az eltelt idő alatt a fa beszáradása miatt. A fán a balta rozsdásodása sötét elszíneződést okozott. A baltát a nyélre alulról húzták fel, mert a nyél felső részén egy kis kiálló körperem van a fa anyagában, ami megakadályozza az acél lecsúszását, tehát felülről a baltát nem lehet a nyélre ráhúzni. A balta anyaga acél, súlya 65 dkg, a nyeles balta összsúlya 109 dkg. Szép, igényes kovács munka.

A nyélen egy vers, két pásztor alak, életfák, virágok és egy visszafelé írt név is található. A karcolozott nyél díszítése hosszában három fő részre osztott: felső rész $32 \mathrm{~cm}$, középső rész $22 \mathrm{~cm}$, alsó rész $26 \mathrm{~cm}$ hosszú. A nyél felső vége kissé ferdén van levágva, rajta egy spanyolozott virággal, míg az alsó vége merőleges, a használattól szélei körben kissé felpöndörödve.

A nyél részletes ismertetése továbbiakban fentről lefelé sorrendben történik. A nyél felső végén spanyolozott (3. ábra) virág motívum nyolc gömbölyű, csepp alakú szirommal, kör középpel. A szirmok és a körközép körüli kör alakú mező bordó, a szirmok és a virág közép zöld színűek. A bordó kör átmérője 2,6 cm (4. ábra). A balta alatt $1,9 \mathrm{~cm}$ magas spanyolozott körszalag, benne alulról felfelé álló teli háromszögekkel. Ezek egymást váltó színei: 2 fekete, 2 zöld és 3 piros. A szalag felső vonalától lefelé álló $\mathrm{V}$ alakok az alsó háromszögek között: 4 zöld, 2 piros és 1 fekete.

A felső rész alján áll a 7,8 cm magas felső férfi pásztor alak, felette $23,5 \mathrm{~cm}$ magas életfa ábrázolás: korsóból kinövő „S“ alakú kacskaringós száron zárt, szorosan egymáshoz érő gömbölyített végü, íves levelekkel, amin gömbölyű végű, nagy szirom jellegű, kis körközepű virág van. A virágok: $5 \mathrm{db}$ nyolc szirmú, $1 \mathrm{db}$ kilenc szirmú, minden második sziromlevél sraffozott. A virágok között 7 db íves csepp formájú, szorosan egymáshoz érő levélsor, ezek $3 \mathrm{db}$ nyolc leveles, $2 \mathrm{db}$ hét leveles, $1 \mathrm{db}$ hat leveles és a legfelső két kis leveles. A virágszár legtetején jobbra-balra álló szív alakú levél van, alsó szárról, de a szártöveikből felfelé háromszög csúcs alakú két vonal is van, mintegy lezárásként. Az alak mögött hasonló kialakítású, $32 \mathrm{~cm}$ magas életfa ábrázolás található, csak a nyél csomója (péterszeg) miatt szélesebb edényből kinövő életfával, melynek kacskaringós szárán 9 levél szakasz és 8 virág van. A levél csoportok $2 \mathrm{db} 6,2 \mathrm{db} 7$, $3 \mathrm{db} 8,1 \mathrm{db} 9$ és $1 \mathrm{db} 10$ leveles kialakítással. A $3 \mathrm{~cm}$ átmérőjű virágok mind 8 szirmúak, kis kör középpel, mint a rövidebbik életfánál. Itt is minden második levél és szirom sraffozott. A férfi alak kissé széttett lábakkal álló juhász ünneplöben, lábán hegyes orrú, magas sarkú, ráncos szárú csizma, sok függőleges ráncú „rödösgyatya“, mely a fél csizmaszárig ér. Zsinóros, begombolt, svájfolt, hoszszú ujjú rövid kabát, kis karimás kalap, vékony, kihúzott, hosszú bajusz. Szemek üres mandula alakok szemgolyó nélkül, szemöldök, orr, száj megrajzolva. Bal oldalon fülét takaró, a fül aljáig érő lelógó sima haj. Bal keze a csípőjén, jobb kezével a baltára támaszkodik annak a fokát fogva, míg a balta éle kifelé áll. Megjelenésében hasonlít az alsó alakhoz.

A bot középső részén csak két, $21 \mathrm{~cm}$ magas növényi ornamentika ábrázolás található, a szakasz aljáról kezdődve hasonló kialakítással, mint a felső mezőben. Mindkettő életfa-típusú, korsóból nő ki (5. ábra). Minden virág $8 \mathrm{db}$ hegyes végü, buzsáki típusú kis körközepű szirommal, minden második szirom sraffozva, nagyságuk $3,5 \mathrm{~cm}$. A virágok mellett „S” alakú száron mindkét irányban csepp alakú, de hegyes végü, szorosan összeérő levelek vannak, kivéve ahol a virág csatlakozik a szárhoz. Az egyik életfán 5 , a másikon 6 virág van. Az 5 virágos szár végén 1 db szív alakú, balra mutató levél van végződésként.

A bot alsó harmadán legalul egy $12 \mathrm{~cm}$ magas, körbe érő bekarcolt vers, felette az álló alsó alak, mely mögött kacskaringós folyóírással visszafelé írva 10,5 $\mathrm{cm}$ hosszon (6. ábra) Szibenliszt Béla név, az írás végén 9 rövid kis párhuzamos vonalkával, ami két ovális forduló után hosszú névaláhúzás lesz, melynek vége többször kanyarodva egymásba ellentétesen befordult fekvő $B$ betű alaknak látszik. Hossza a név alatt végig ér, mint egy cirkalmas befejező, diszítő aláhúzás. A visszafelé írt, bekarcolt név tükörképi olvasata: Szibenliszt Béla. A folyó írással karcolt vers (7. ábra) a nyél alsó részén:

Somogyba a kanászok
Olyak mind a királyok
Hatalmassak a csárdába
Mind király a palotába
Kezökben van a balta
A bajczuk ki van huzva
Olyanok mind a király
Velök az urse tréfál
Neki mennek a tüznek
Nemis néznek csak ütnek.

A vers utolsó sorának alja a nyél alsó vége felett 13 cm-re végződik, alatta már nincs karcolozás.

Az alsó, 9,3 cm magas karcolt férfi alak vigyázz állásban álló, szembe néző kanász jobb kezében a fej fölé feltartott kanász baltával, melynek éle a fej felé mutat. Teljes magassága a baltával $10,5 \mathrm{~cm}$. Jobb keze csípőre téve. Ruházata azonos a felső alak ruházatával, csak szorosan egymás mellett vannak a lábai. A bal vállon átvetett vastag tölténytartó szíjhoz hasonló szíj, melynek alján a balta tartó karika, amiről tovább lóg a pásztorkészség. Jobb vállon átvetett szíj, melyen bal deréknál a becsukott bőr pásztor táska lóg. Begombolt nyakú ing, kétoldali szalag kötővel. Fej jobb oldalán kevés, bal oldalán több lelógó, sima hajjal. 


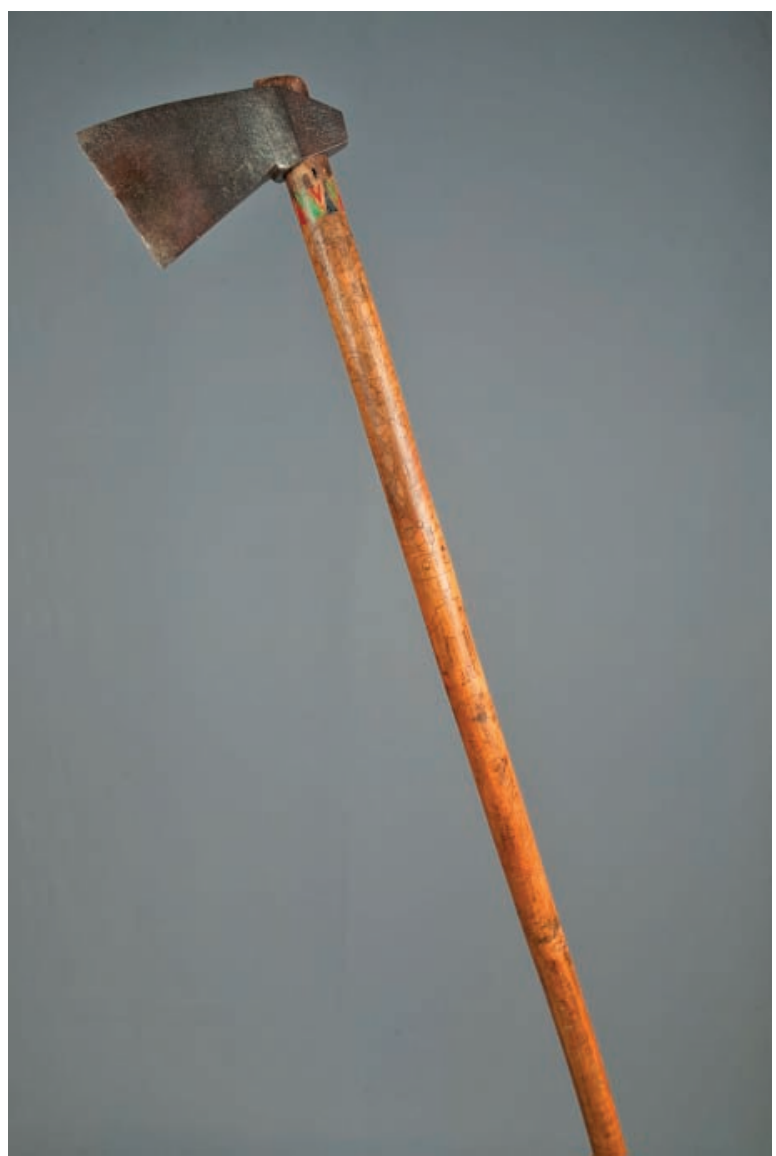

2. ábra. A kanászbalta

A balta készítője - eddigi információim szerint - számomra ismeretlen, szignója nincs a nyélen, de egy igen gyakorlott, ügyes kéz remekműve. Nagyon magabiztos késvezetés látható, igen kevés a „kifutott“, rontott karcolás nyom. A nyélen szereplő név leginkább a balta tulajdonosának a neve lehet, akinek készítették. Mivel Szibenliszt Béla (1852 Kőszeg - 1936 Várda) 1910-től várdai nyugdíjasként foglalkozott a helyi népszokásokkal, azokat összegyűjtötte és leírta, majd 1914-ben ezen dolgozatát Varga Sándor várdai tanítónak átadta, így érdeklődési köre alapján akár neki is készíthették a nyelet, egy régi, talán általa gyűjtött acél baltához. Mivel a név mint felirat a kompozícióba gondosan bele-

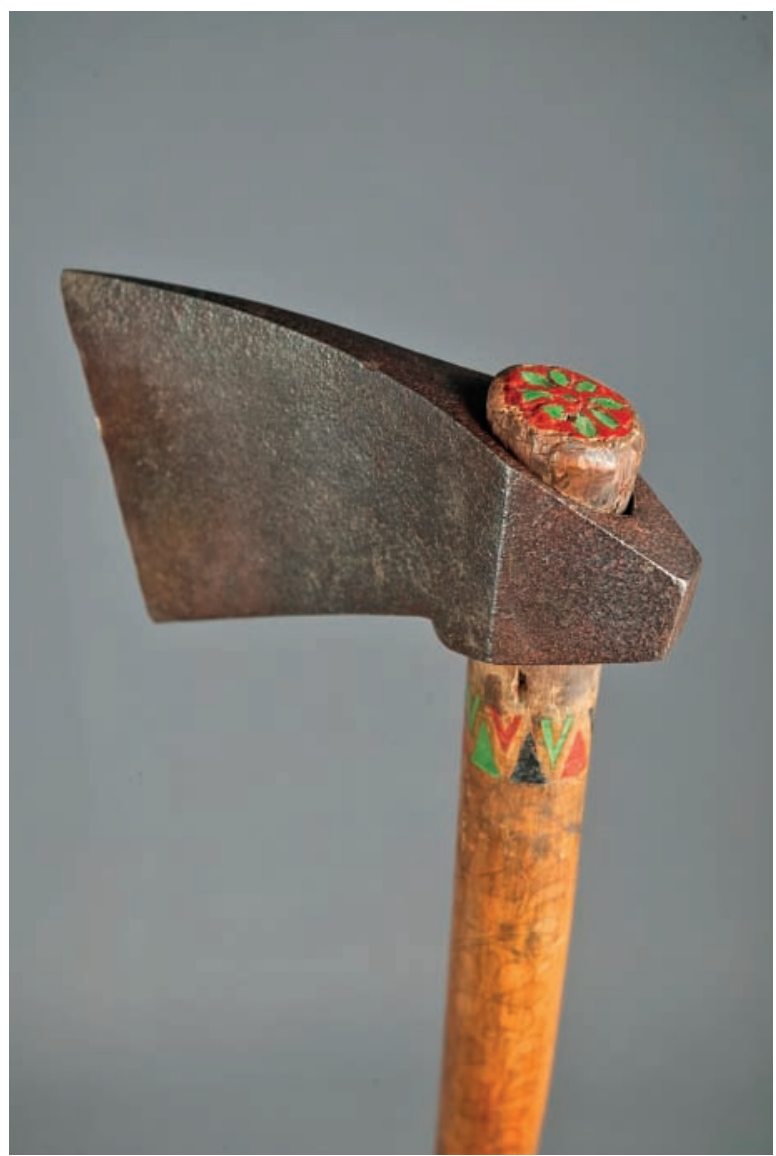

4. ábra. A balta felső része

szerkesztett, nem valószínű hogy utólag karcolták bele a nevet. A név bekarcolása azonos kéz munkája lehet, mint a diszítések karcolásai, mivel a kompozícióba pontosan szerkesztett, karcolási technikája azonos az életfa motívumok és az alakok elkészítésével. Bár a készítő személye ismeretlen, feltehetőleg egy Várda környéki pásztorember lehetett, talán épp Szibenliszt Béla megrendelésére készítette a nyelet.

A nyélen szereplő verset Szibenliszt gyűjthette, és talán megadta a nyél faragójának, hogy a fordított írású nevéhez hasonlóan ezt is illessze be a kompozicíóba a pásztor alakokkal együtt. A név és a vers írásmódja egy korabeli stílusú folyóírás, amit akár a megrendelő
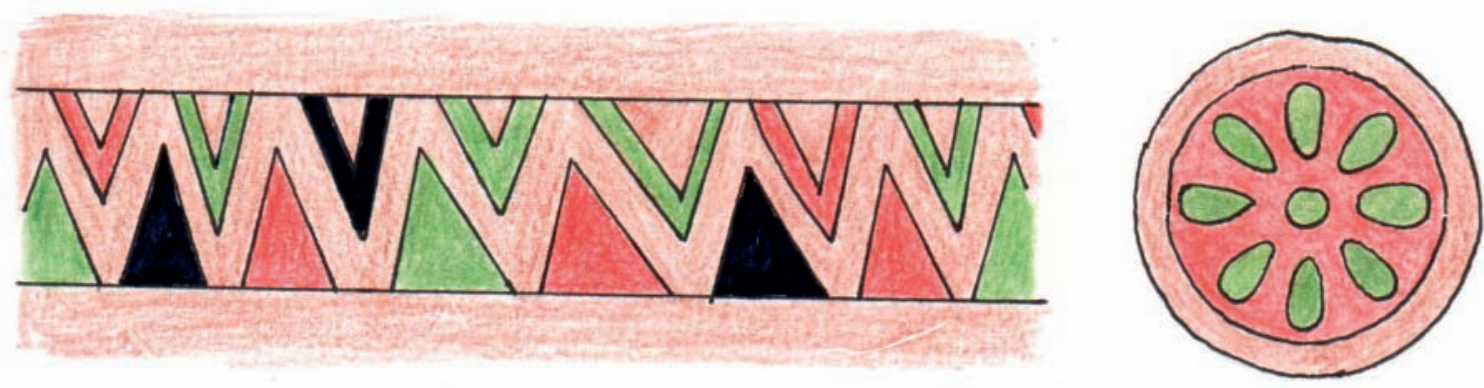

3. ábra. Spanyolozott díszítések rajza 
302

BERZY PÉTER

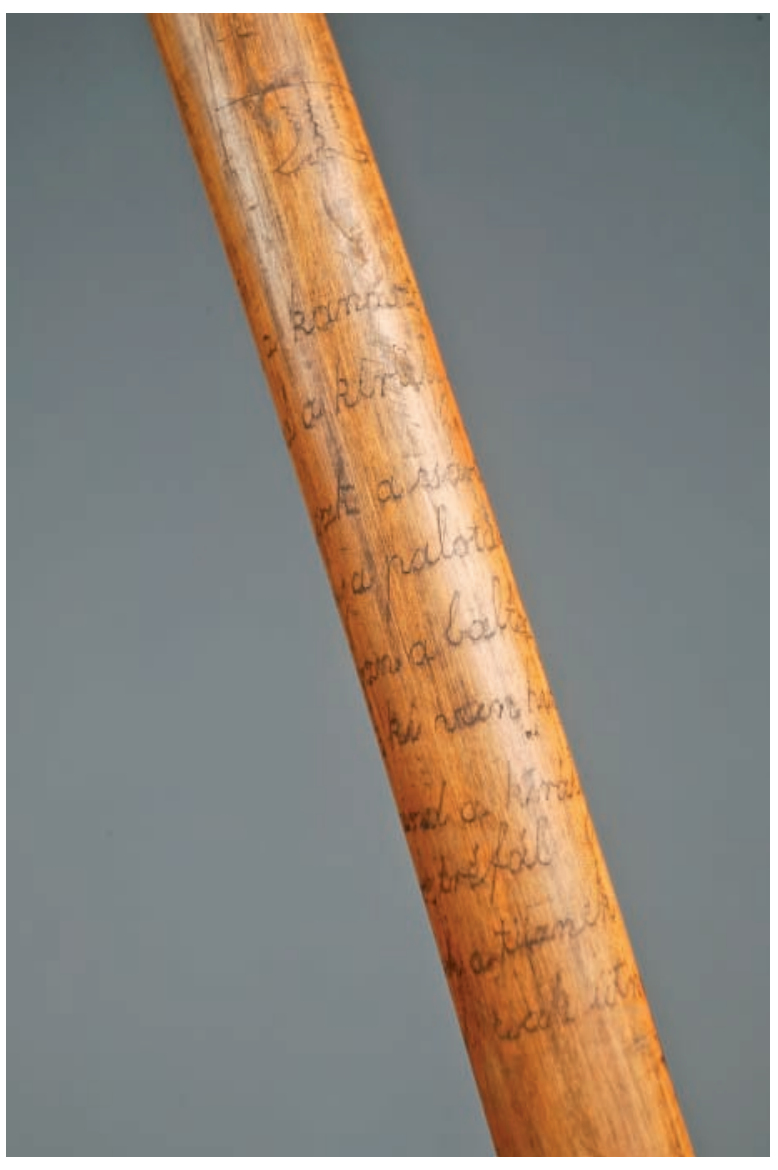

5. ábra. A nyél díszítése

is leírhatott a faragónak, hogy másolja le. Az acél balta készítője kovács ember kellett legyen, de monogram, jel hiányában ismeretlen a személye és a készítés ideje. Stílusát tekintve a régi klasszikus somogyi íves nyelü kanászbalta. A nyél készítés időintervalluma mindenképpen az első világháború előtti időszak, valószínű Szibenliszt néprajzi vonatkozású gyűjtő munkásságának (1910-1914) időszaka.

Szibenliszt Béla rövid életrajza

A nyélen szereplő Szibenliszt Béla (8. ábra) és családtagjainak rövid életrajza, részben Puskás Béla adatainak felhaszálásával, szerző levéltári és könyvtári kutatásaival kiegészülve az alábbiakban foglalható össze. Apja Szibenliszt János katonatiszt, anyja báró Schmidthals Berta. Szibenliszt Béla 1852-ben született Kőszegen, ahol élete első éveit töltötte. A Műszaki Egyetemet Bécsben végezte, majd apja nyomdokain katonai pályára lépett. A katonai iskolák elvégzését követően 37 éven keresztül az utász alakulatnál szolgált. Pozsonyban zászlóaljparancsnok, majd Székesfehérváron ezredparancsnok volt. A boszniai okkupációban (1878. július - november) főhadnagyként vett részt. Kitüntették a III. oszt. vaskoronarend, a Signum Laudis, a Toszkánai Nagyhercegség érdemkeresztjével, vala-
Sribenlist Cóla

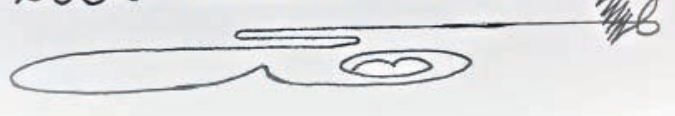

6. ábra. A bekarcolt név tükörképe

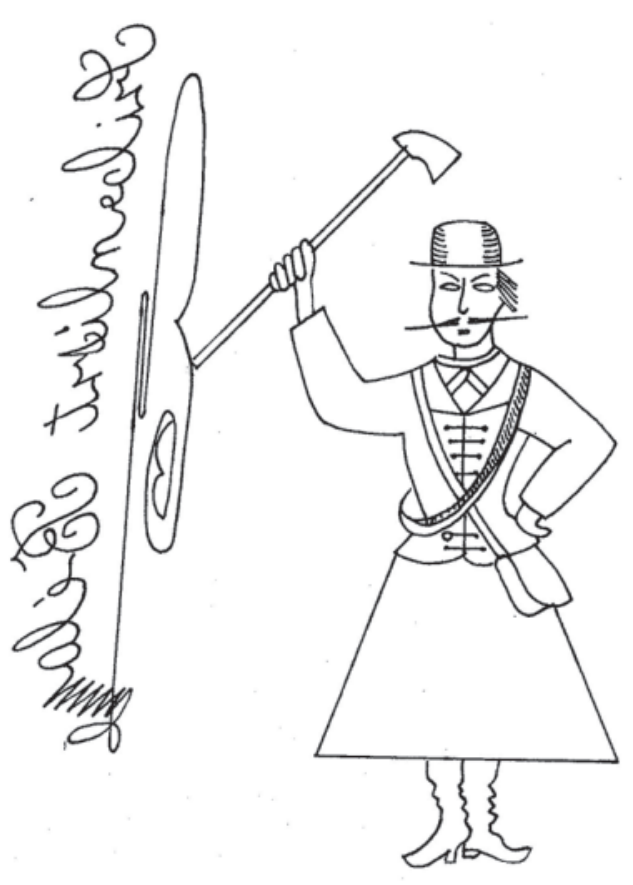

Oomagyba a kanászok Oyak mind a kirälyok Latalmassak a csárdába Mind király a palotába Reriokhen van a halta A bajousts ki van hurwo Olyanok mind a király Celók az urse tréfál cleki mennek a tïrnek femistrérnek csak ütruek.

7. ábra. A név, a pásztor alak és a vers rajza 
mint a közös- és honvéd-hadiéremmel. Házasságot kötött, később elvált. 1903-ban a 23. gyalogezred 2-ik zászlóalj (74 Nagyszeben) parancsnoka őrnagyként. 1904-ben ezredessé avatták. 1910-ben 58 évesen ezredesként ment nyugállományba. ${ }^{5}$

Ezt követően Várdán telepedett le, valószínű azért, mert ott élt az akkor 60 éves nővére Mérey Józsefné született Szibenliszt Janka is, a mai Fő utca 94. számú lakóházban, ami jelenleg a posta épületeként szolgál. Felesége már nem jött Várdára lakni. Tevékeny életet élt itt is. ${ }^{6}$ Adományokkal segítette a várdai iskolát, könyvtárat, valamint a Vármegyei Múzeumot. 1914-re elkészítette és átadta az iskolának a Várdai Népszokások Gyüjteménye című írását. 1923-ban Budapesten lakott. 1924-ben megírta és kiadta Séta Szigetvár körül címmel ismeretterjesztő füzetét. 1936 június 2-án este 21 órakor 84 évesen aggkori végkimerülésben hunyt el Várdán, ott helyezték örök nyugalomra.

A „Várdai Népszokások Gyüjteménye” címü munkáját Varga Sándor, a falu szeretett tanítója kapta meg 1914-ben a szerzőtől. A tanító úr az 1950-es évek végéig, 47 éven át tanított Várdán, a község díszpolgára volt. Felesége a szentbalázsi Ternóczi Mári volt, lá-

$5 \quad$ Honvédelmi Minisztérium: Zárszámadás 1908. kimutatás 135. oldalán található: „Szibenliszt Béla ezredes (1852-) évi 8800 Korona jövedelemmel. Szolgálati ideje 37 év 1 hónap 20 nap, nyugdíja $1100 \mathrm{~K}$ lév többlet az 1907 évben megállapított $6600 \mathrm{~K}$ várakozási illetékben, mert évi $7200 \mathrm{~K}$. javadalmaztatása az 1908. évi XXVII. t.-cz. 8.§-a alapján 8800 Kra emeltetett." Az írott hivatalos forrásokban a nevet néha Sziebenliszt, általában Szibenliszt - nek említik, a hiteles a Szibenliszt változat, mivel az fordul elő legtöbbet a hivatalos iratokban, könyvei szerzőjeként, sírján, saját baltáján is. A Honvédelmi Minisztérium kimutatásában 1908-ban ezredes a rangfokozatának megjelölése, ami a törzstisztek kategóriában a legmagasabb fokozat, mint: őrnagy, alezredes, ezredes. Varga Imre kutató szerint a 29572 nyilvántartási számon: Szibenliszt Béla ezredesi rangfokozattal ment nyugdíjba.

A Temetők üzenete könyv „Várda“ c. részében Szibenliszt Béla 1910-ben már vezérőrnagy-ként van említve, ami a „Császári és Királyi Hadsereg rendfokozatai 1908-ig“ kimutatása szerint a tábornokok kategóriába tartozik.

Ugyanakkor a Fögimnáziumi eseményen 1912-ben a rangjelzése már tábornok, ami egy még magasabb kategória, melyben a felfelé sorrend: vezérőrnagy, altábornagy, gyalogsági,-lovassági tábornok, vezérezredes, táborszernagy.

A Budapest Czím- és Lakásjegyzék második részben: Szibenliszt Béla tábornok 1923-ban Budapest VII. Rákóczi út 29. alatt volt bejelentkezve, mint állandó lakos. Fia Budapesten tanult jogot, és késöbb ott dolgozott.

Nyugdíjazásakor 1908-ban törzstisztként ezredesi rangfokozata volt, amit a korabeli HM. Kimutatás igazol egyedül hitelesen. A már 2. éve nyugállományú törzstiszt elöléptetéséröl 1910-ben vezérőrnaggyá, majd 1912-ben tábornokká, a fentebb említetteken kívül nem található más bizonyíték, bár az általa írt, nyomtatásban megjelent kis szigetvári könyvére nem véletlenül kerülhetett a magasabb rendfokozat, mely szerint nyugállományában is elöléptethették. Így került a szigetvári kis könyvre 1924-ben a tábornok megjelölés. Sírján is tábornok felirat van 1936-ból.

A Szibenliszt, és a Schmidhals családnevek sajnos nem találhatók sem a Nagy Iván sem a Kempelen Béla szerzők által jegyzett magyar és magyar nemesi családokról szóló kötetekben.

6 A Kaposvári Magyar Királyi Állami Fögimnázium Emlékkönyve c. könyvben olvasható, hogy 1912 november 5-én a gimnázium tornatermében 11 órai kezdettel Csertán Márton ref. lelkész és Herczog Manó dr. főrabbi által a protestáns és az izraelita vallású tanulók számára tartott istentiszteleten részt vettek a Kaposváron és környékén élő megyei és városi vezetők, főurak, előkelőségek, köztük Szibenliszt Béla nyugalmazott tábornok.

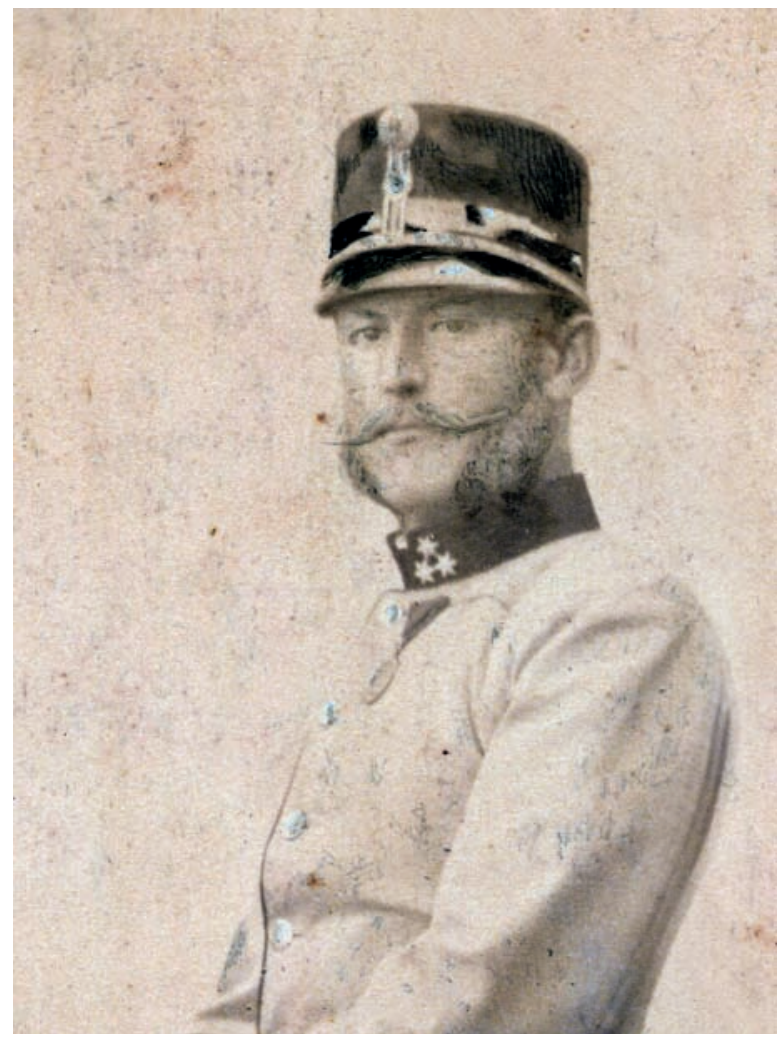

8. ábra. Szibenliszt Béláról 1890-ben, 38 éves korában készült ceruzarajz fotója, a Monarchia k.u.k hadseregének egyenruhájában. A 40×40 cm nagyságú, bekeretezett fénykép egy padlásról került elö, jelenleg magángyüjteményben van

nyaik Joli 1916, Babi 1919 születésűek. Egyik lányától helybéli lokálpatrióták szerezték meg az írott és képi hagyatékok maradékát, de az említett dolgozat sajnos nincs köztük. Holléte ezideig ismeretlen, sem a Magyar Néprajzi Múzeum, sem a Rippl-Rónai Múzeum, sem a Várdai Önkormányzat, sem a Somogy megyei Levéltár, sem a megyei könyvtári hálózat nem tud az írás hollétéröl. Előkerülése talán magyarázatot adhatna a kanászbalta készítőjére és a rajta lévő névvel való kapcsolatára. Mindezektől függetlenül a balta egy igen mutatós, szép, néprajzi tárgyi gyűjteménybe illő, ép, tipikus régi somogyi darab.

\section{Köszönetnyilvánítás}

Köszönöm a cíkk adatszolgáltatásában résztvevők: Várda Község Önkormányzata dolgozói, Varga András polgármester, Tóth György Zsolt képviselő és falugondnok, Üst Roland képviselő, a Somogy Megyei levéltár, a Takáts Gyula Megyei és Városi Könyvtár, valamint a Szibenlisztékkel valamikor szemben lakó Kisiván Ferencné Rózsi mama önzetlen segítségét. Külön köszönöm a cikk megjelenítését segítő Rippl-Rónai Múzeum munkatársainak önzetlen segítségét. 


\section{Irodalom}

BoNA G. 2000: Tábornokok és törzstisztek az 1848/49. évi szabadságharcban. - Heraldika Kiadó, Budapest.

BUdAPEST CZÍM- ÉS LAKÁSJEGYZÉK 1922-1923: 28. évfolyam. - Kiadja FRANKLIN - TÁRSULAT Magyar Irod. Intézet és Könyvnyomda.

DIRRHEIMER, G. 1997: Das k.u.k. Heer 1895. Eine Bildserie. - Edition Leopold Stocker, Graz.

EÖTVös K. 1901: Emlékezések. - Révai testvérek, Budapest.

HALOTTI ANYAKÖNYV VÁRDA. 1936: 10. sorszám alatt Szibenliszt Béla.

HALOTTI ANYAKÖNYV VÁRDA. 1940: 8. sorszám alatt Szibenliszt Janka.

HeRman O. 1898: Ősfoglalkozások. Halászat és pásztorélet. - Pesti Könyvnyomda Részvénytársaság, Budapest

HONVÉDELMI MINISZTÉRIUM ZÁRSZÁMADÁS 1909: KIMUTATÁS aZokról az állami nyugdíjasokról, a kik az 1908. évben nyugalmaztattak. Továbbá azokról az özvegyekröl és árvákról a kik az említet évtől kezdve állami ellátást élveznek. - Budapest.

IGAZSÁGÜGYI KÖZLÖNY 1915 24. ÉVFOLYAM 8. SZÁM: 512. oldal. Dr Szibenliszt Henrik.

IGAZSÁGÜGYI KÖZLÖNY 1946 55. ÉVFOlYAM 4. SZÁM: 155. oldal. Dr Szibenliszt Henrik.

IGAZSÁGÜGYI KÖZLÖNY 1948 57. ÉVFOlYAM 1. SZÁM: 26. oldal. Dr Szibenliszt Henrik.

IHAROSI PLÉBÁNIA HALOTTI ANYAKÖNYV INKE 1887: 7. sorszám alat Szibenliszt János.

S. Kovács I. 2001: Pásztorművészet. In: Kapitány O. és Imrő J. (szerk.): Somogy megye népművészete. - Somogy Megyei Múzeumok Igazgatósága, Kaposvár, 329-372.

KAPOSVÁRI MAgYAR KIRÁlYI ÁlLAMI FÖGIMNÁZIUM EMLÉKKÖNYVE 1812 1912. 1913: A kaposvári állami fögimnázium százados emlékünnepe 1912. november 5-én. - Szabó Lipót Könyvsajtója.
Kempelen B. 1911: Magyar nemes családok. - 9-10. kötet. Grill Károly Könyvkiadó Vállalata, Budapest.

KósA KÁROLY HONLAPJA: Jász-Nagykun-Szolnok megyei és kárpátmedencei „böngészet“ SZOLNOKI DIADAL 1849. március 5. én. Az 1849. január 22-én és március 5 -én vívott szolnoki ütközet hösei (szemelvények a teljesség igénye nélkül) Szibenliszt János.- Forrás: Gracza Gy. Budapest 1894-98. kosakaroly.hu/ adattar/1849/honved.html 2020.01.10

MANGA J. 1980: Kanászbalta, kondásbalta. In: Magyar Néprajzi Lexikon III. (főszerk.: Ortutay Gyula) - Akadémiai Kiadó, Budapest: $18-20$

MAgYARORSZÁG TISZTI CÍM- ÉS NÉVTÁRA 1903: 22. évfolyam 795. oldal. Szibenliszt Béla.

MAgYARORSZÁG TISZTI CíM- ÉS NÉVTÁRA 1918: 37. évfolyam 472. oldal. Dr. Szibenliszt Henrik.

MAGYARORSZÁG TISZTI CÍM- ÉS NÉVTÁRA 1936: 44. évfolyam 390. oldal. Dr. Szibenliszt Henrik.

MALONYAY D. 1911: A magyar nép művészete. III. kötet. - Franklin Társulat, Budapest.

NAGY I. 1860: Magyarország Családai czímerekkel és nemzedéki táblákkal „B”.- Kiadja Ráth Mór Budapest.

Puskás B. 2001: Temetők üzenete. Várda.- Kaposvári Nyomda Kft. Kaposvár.

SziBEnLISzT B. 1924: Séta Szigetvár Körül. - Kiadja: a „Zrínyi Miklós Múzeum Egyesület Szigetvár“ „Új Délsomogy Könyvnyomda“ Szigetvár.

TAKÁTS GY. 1986: Somogyi pásztorvilág - Somogy Megyei Múzeumok Igazgatósága, Kaposvár.

TÁLASI I. 1939: A bakonyi pásztorkodás - Etnographia 50. évfolyam: 33-34. 